\title{
Cytomegalovirus infection among Human Immunodeficiency Virus (HIV) infected individuals on highly active anti-retroviral therapy in North-Central Nigeria
}

\author{
Augustine Udeze ${ }^{1}$, Mutiat Odebisi-Omokanye ${ }^{2}$, Toluwani Ajileye ${ }^{1}$
}

1. Virology Unit, Department of Microbiology, University of Ilorin, P.M.B 1515 Ilorin-Nigeria.

2. Infectious Disease, Environmental Health and Toxicity Research Group, Department of Microbiology, University of Ilorin, P.M.B 1515 Ilorin Nigeria.

\section{Emails:}

1. Augustine O Udeze: Email: udeze.ao@unilorin.edu.ng, austok90@yahoo.com

2. Mutiat B Odebisi-Omokanye: Email: odebisimutiat@yahoo.com

3. Toluwani G Ajileye: Email: Ajileye017@yahoo.com

\begin{abstract}
Background: Cytomegalovirus (CMV) infection is common among HIV-infected individuals. Its contribution to morbidity and mortality became more apparent following introduction of highly active anti-retroviral therapy (HAART) which improved survival among HIV-infected individuals.

Objectives: This study aimed at determining the prevalence of both active and latent CMV infections among HIV-infected individuals on HAART in Ilorin, Nigeria.

Methods: A total of 360 consented HIV-1 patients were recruited for the study. About $5 \mathrm{ml}$ of blood and socio-demographic data were collected from each patient. Plasma from the blood was tested for anti-CMV IgM and IgG presence using ELISA.

Results: Of the 360 participants tested, $42(11.7 \%)$ and $265(73.6 \%)$ were respectively anti-CMV IgM and IgG antibodies positive representing active and latent infection rates respectively. Gender and age were the correlates of IgM seropositivity while age, occupation and marital status correlated with IgG seropositivity. Occupation, marital status, use of HAART and CD4 ${ }^{+}$ count were not statistically associated with IgM level while gender, use of HAART and $\mathrm{CD}^{+}{ }^{+}$count did not correlate with IgG level.
\end{abstract}

Conclusions: This study has demonstrated high level of latent and active CMV infection among HAART recipients in Ilorin and highlighted the need for incorporation of anti-herpes drugs in the treatment regimen.

Keywords: HIV, CMV, HAART, latent and active CMV infection.

DOI: https://dx.doi.org/10.4314/ahs.v18i4.27

Cite as: Udeze A, Odebisi-Omokanye M, Ajileye T. Cytomegalovirus infection among Human Immunodeficiency Virus (HIV) infected individuals on highly active anti-retroviral therapy in North-Central Nigeria. Afri Health Sci. 2018;18(4): 1057-1065. bttps://dx.doi.org/10.4314/abs. v18i4.27

\section{Introduction}

Opportunistic infections (OIs) remain a major concern in Human Immunodeficiency Virus (HIV) infected in-

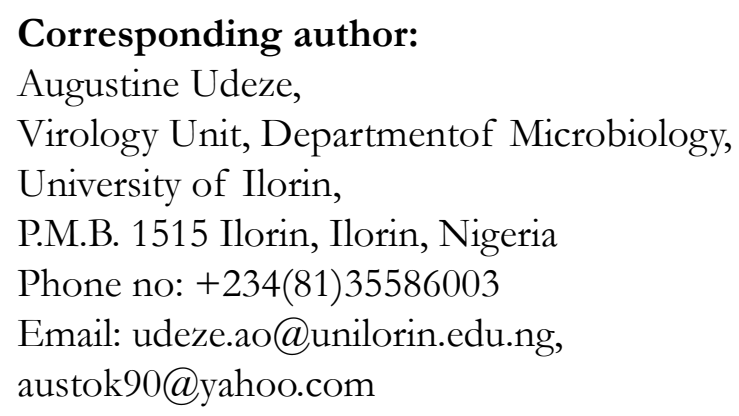

dividuals as they contributes significantly to morbidity and mortality and are the main reason for hospitalization among this cohort ${ }^{1}$. OIs in HIV-infected individuals can be caused by viruses, bacteria, fungi, protozoa and other pathogens. Among the leading cause of viral OIs in HIV-infected individuals are viruses belonging to Herpesviridae family including human herpes simplex virus types 1 and 2 (HSV-1 and HSV-2), Cytomegalovirus (CMV), Varicella zoster virus (VZV), and Epstein - Barr virus (EBV).

CMV (a member of the Betaherpesvirinae sub-family) has global endemicity and is more widespread in developing countries particularly in areas of low socio-economic 
conditions $^{2}$. Its seroprevalence in the general population ranges from $50 \%$ to $90 \%{ }^{3}$ and increases to $75 \%$ to $90 \%$ in HIV-infected individuals particularly among homosexual men ${ }^{4}$. It is transmitted principally through infected body fluids, sexual contact, blood transfusion, during delivery and during organ transplant. The virus establishes a lifelong latent infection in infected individuals principally in connective tissue cells, such as the endothelium of blood vessels, mononuclear cells, white blood cells, and epithelial cells. The infection is often asymptomatic and acute and is followed by lifelong persistence of the virus in a latent stage in immunocompetent subjects but with potentially severe consequences in immunocompromised patients ${ }^{5}$. In people with HIV infection, it can present with a wide array of complications such as gastrointestinal tract ulceration, hepatitis, encephalitis, retinitis, leukopenia and respiratory infections ${ }^{6,7}$. The prevalence of these end-organ diseases (EODs) was estimated at approximately 40\% or greater among patients with advanced HIV infection prior to the era of Highly Active Antiretroviral Therapy (HAART) ${ }^{8}$. The advent of HAART however led to improved prognosis among HIV patients with significant reduction in EODs.

Whether CMV acts as a cofactor in accelerating HIV pathogenesis or activates opportunistically, without clinical consequence, as a result of the general impairment in cellular immune responsiveness caused by HIV is not yet fully understood ${ }^{9,10,11,12,13}$. Since both viruses are immunosuppressive, synergistic effect culminating in accelerated disease progression ${ }^{14}$ cannot be completely ruled out. A number of studies have implicated CMV as a cofactor in the pathogenesis of AIDS $^{15,16,17,18}$ although its direct effect has been difficult to document since most adult patients are infected with CMV long before becoming infected with HIV-1 $1^{16,17,19}$.

A crucial part of immune system defence against CMV is the development of CMV specific antibodies. The first type of antibody to develop in response to CMV is IgM, which develops within a few days following primary infection. While CMV IgM remains detectable for six to nine months, medium to high levels of CMV IgM can be detected during the first three months of a primary infection. IgM is also detected during secondary infections either as re-activation or re-infection. The second antibody type to respond to CMV is IgG. This antibody develops within 1 to 2 weeks after infection and, once de- veloped, can be detected throughout life. Consequently, IgG is commonly used and widely accepted measure of previous/latent CMV infection ${ }^{20}$ because this virus establishes a lifelong latent infection in infected individuals. The aim of the present study was to evaluate previous/ latent visa vis current/active CMV infection and associated predictors among a cohort of HIV-infected individuals majority of whom are on HAART in Kwara state, North-Central Nigeria.

\section{Methods}

\section{Study design and population}

This was a cross-sectional, hospital-based cohort study conducted between January and July 2016. The study participants included 360 (93 males and 267 females: age range 1 - 70 years; mean age 42 years) confirmed HIV-infected individuals attending an anti-retroviral treatment center at General hospital Offa, Kwara state. Socio-demographic data were collected using interviewer-administered questionnaire forms from the study participants.

\section{Sample collection and preparation}

Consenting participants were consecutively selected in the hospital irrespective of age, state of health and gender; exclusion criteria were; no willingness to participate. Blood samples were aseptically collected by venipuncture from the participants. About $5 \mathrm{ml}$ of blood sample was obtained from each participant into a sterile bottle and allowed to clot at room temperature before spinning at 3,000 rpm for 10 minutes. Then serum was aspirated into new Eppendorf tubes, appropriately labelled and stored at $-20^{\circ} \mathrm{C}$ until assayed.

\section{Serology}

Serum samples were tested for the presence of $\operatorname{IgM}$ and IgG antibodies using commercially available Enzyme Linked Immunosorbent Assay (ELISA) kit (manufactured by Diagnostic Automation, Inc., Calabasas, CA, USA) for detection of CMV specific IgM and IgG antibodies. The tests were performed and interpreted according to the kits' manufacturer's instructions.

\section{Ethical clearance}

Ethical clearance for the study was obtained from the Ethical Review Committee (ERC) of Kwara state Ministry of Health, Nigeria. Approval was also obtained from the hospital involved in this study. There was informed 
consent from all the participants and parents of the participants in the case of children before sampling.

\section{Statistical analysis}

Data was analysed using Statistical Package for Social Sciences (SPSS version 21). Chi square or Fisher's exact was used where appropriate to test association. A p value of $<0.05$ was considered significant.

\section{Results}

Of the 360 samples tested, $42(11.7 \%)$ tested positive foranti-CMV IgM antibody while 265 (73.6\%) tested pos- itive for anti-CMV IgG antibody. Samples were collected from $93(25.8 \%)$ males and $267(74.2 \%)$ females (Table $1)$. The study shows significant difference $(X 2=5.32$, $\mathrm{p}$-value $=0.021)$ in the distribution of anti-CMV IgM antibody between the two gender groups. Higher prevalence of anti-CMV IgM antibody was detected in males $(18.3 \%)$ than females $(9.4 \%)$. On the other hand, there was no significant difference $(\mathrm{X} 2=0.48, \mathrm{p}$-value $=0.488)$ in the distribution of anti-CMV $\operatorname{IgG}$ antibody between the two groups. The prevalence of anti-CMV IgG antibody was also higher in males $(76.3 \%)$ than in females $72.7 \%$ (Table 1).

Table 1: Relationship between study predictors and detection of anti-CMV IgM/IgG antibodies among the HIV-infected study participants

\begin{tabular}{|c|c|c|c|c|c|}
\hline \multirow[t]{2}{*}{ Predictors } & \multirow[t]{2}{*}{ No tested } & $\begin{array}{l}\text { No }(\%) \\
\text { positive }\end{array}$ & \multirow[t]{2}{*}{$X^{2}$ (p-value) } & $\begin{array}{l}\text { No }(\%) \\
\text { positive }\end{array}$ & \multirow[t]{2}{*}{$X^{2}$ (p-value) } \\
\hline & & IgM & & IgG & \\
\hline \multicolumn{6}{|l|}{ Gender } \\
\hline Male & 93 & $17(18.3)$ & \multirow[b]{2}{*}{$5.32(0.021)$} & $71(76.3)$ & \\
\hline Female & 267 & $25(9.4)$ & & $194(72.7)$ & $0.48(0.488)$ \\
\hline \multicolumn{6}{|c|}{ Age group (years) } \\
\hline$\leq 20$ & 14 & $3(21.4)$ & & $12(85.7)$ & \\
\hline $21-30$ & 46 & $1(2.2)$ & & $33(71.7)$ & \\
\hline $31-40$ & 121 & $15(12.4)$ & & $85(70.3)$ & \\
\hline $41-50$ & 89 & $7(7.9)$ & & $52(58.4)$ & \\
\hline $51-60$ & 52 & $11(21.2)$ & \multirow[b]{2}{*}{$11.251(0.0466)$} & $46(88.5)$ & \multirow[b]{2}{*}{$29.351(0.0001)$} \\
\hline$>60$ & 38 & $5(13.2)$ & & $37(97.4)$ & \\
\hline \multicolumn{6}{|l|}{ Occupation } \\
\hline Traders & 14 & $28(11.6)$ & & $190(78.5)$ & \\
\hline Civil servants & 46 & $1(4.4)$ & & $5(21.7)$ & \\
\hline Artisans & 121 & $0(0)$ & & $14(82.4)$ & \\
\hline Professionals & 89 & $4(14.3)$ & & $18(64.3)$ & \\
\hline Students & 52 & $2(28.6)$ & \multirow[b]{2}{*}{$6.458(0.2642)$} & $6(85.7)$ & \multirow[b]{2}{*}{$37.316(0.000)$} \\
\hline Unemployed & 38 & $7(16.3)$ & & $32(74.4)$ & \\
\hline \multicolumn{6}{|l|}{ Marital status } \\
\hline Single & 77 & $10(13.0)$ & & $58(75.3)$ & \\
\hline Married & 265 & $32(12.1)$ & & $195(73.6)$ & \\
\hline Divorced & 11 & $0(0)$ & & $10(90.9)$ & \\
\hline Widowed & 7 & $0(0)$ & $2.55(0.4663)$ & $2(28.6)$ & $9.12(0.0277)$ \\
\hline Total & 360 & $42(11.7)$ & & $265(73.6)$ & \\
\hline
\end{tabular}


The study also showed significant difference in both anti-CMV IgM antibody $(\mathrm{X} 2=11.251$, $\mathrm{p}$-value $=0.0466)$ and anti-CMV IgG antibody $(\mathrm{X} 2=29.351, \mathrm{p}$-value $=0.0001)$ among the various age groups tested. It showed that highest prevalence $(21.4 \%)$ of anti-CMV IgM antibody occurred among study participants of age range $\leq 20$ years. Also, highest prevalence (97.4\%) for anti-CMV IgG antibody occurred among participants of age range $>60$ years. Lowest prevalence $(2.2 \%)$ of anti-CMV IgM antibody was observed among subjects of age range 21-30 years while the lowest prevalence $(58.4 \%)$ for anti-CMV IgG antibody was observed among subjects of age range 41-50 years (Table 1).

There was no significant difference $(\mathrm{X} 2=6.458$, p-value $=0.2642)$ in the seropositivity outcome of anti-CMV $\mathrm{IgM}$ antibody among the various occupational groups. On the other hand, significant difference exists in anti-CMV IgG antibody among the various occupational groups in this study $(\mathrm{X} 2=37.316$, $\mathrm{p}$-value $=0.000)($ Table 1$)$. Highest prevalence of anti-CMV IgM antibody $(28.6 \%)$ and anti-CMV IgG antibody (85.7\%) were observed among the students. Lowest prevalence $(21.7 \%)$ of anti-CMV IgG antibody was found among civil servants while an-
ti-CMV IgM antibody was not detected among the artisans in the study group (Table 1).

There was no significant difference $(\mathrm{X} 2=2.55$, $\mathrm{p}$-value $=0.4663)$ in the seropositivity outcome of anti-CMV IgM antibody among the various marital groups in the study. The prevalence was higher among the singles $(13.0 \%)$ than their married counterparts $(12.1 \%)$ while the antibody was not detected among both the divorced and widowed participants. The level of anti-CMV IgG antibody seropositivity among the various marital groups was statistically significant $(\mathrm{X} 2=9.12, \mathrm{p}$-value $=0.0277)$. The prevalence was higher among the divorced participants $(90.9 \%)$, followed by singles $(75.3 \%)$, and married participants $(73.6 \%)$ while widowed participants had the least prevalence $(28.6 \%)$ as shown in table 1.

Our data also shows that 355 out of the 360 (98.6\%) of the study participants were already on HAART while the remaining $5(1.4 \%)$ were ART naive at the time of sample collection. Among the former group, 11.8\% (42/355) and $74.1 \%(263 / 355)$ tested positive for anti-CMV IgM and $\mathrm{IgG}$ antibodies respectively while $40.0 \%(2 / 5)$ prevalence was recorded for anti-CMV IgG antibody among the latter group (Figure 1).

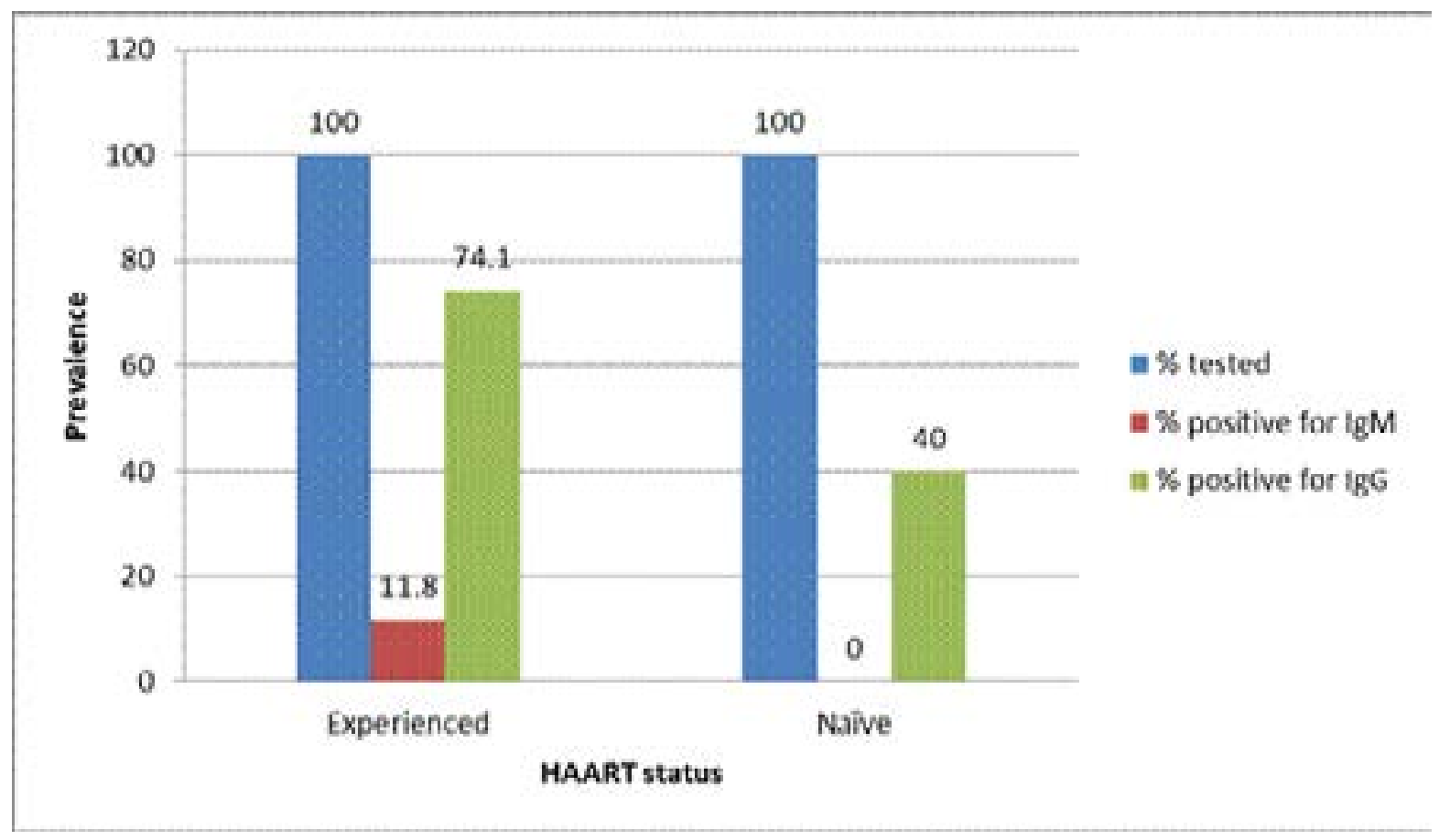

Figure 1: Relationship between HAART status and detection of anti-CMV IgM/IgG antibodies among the $\mathrm{HIV}$-infected study participants Key: HAART = Highly active antiretroviral therapy 
Out of the 360 study participants, $263(73.1 \%)$ had a $\mathrm{CD}^{+}$cell count of $\leq 350 / \mu \mathrm{L}$ while $97(26.9 \%)$ had a $\mathrm{CD}^{+}$cell count of $>350 / \mu \mathrm{L}$. Among the former group, prevalence of $10.7 \%(28 / 263)$ and $71.5 \%(188 / 263)$ for
anti-CMV IgM and anti-CMV IgG antibodies respectively were recorded while in the later group, prevalence of $14.4 \%$ (14/97) and 79.4\% (77/97) for anti-CMV IgM and anti-CMV IgG antibodies respectively were recorded (Figure 2).

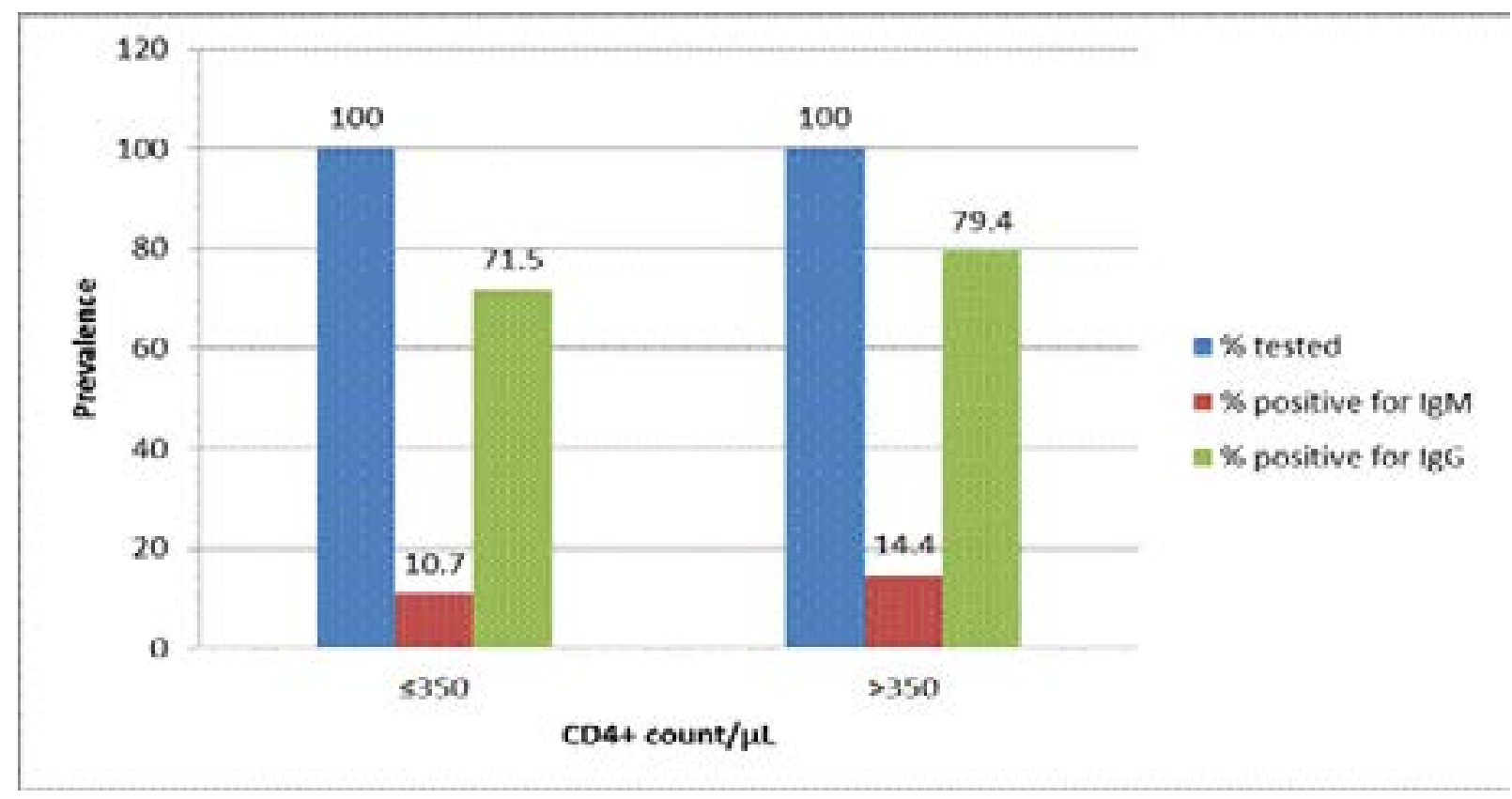

Figure 2: Relationship between $\mathrm{CD4}^{+}$count and detection of anti-CMV IgM/IgG antibodies among the HIV-infected study participants

\section{Discussion}

The $11.7 \%$ and $73.6 \%$ prevalence for CMV IgM and $\operatorname{IgG}$ antibodies recorded in this study is significant and indicates the level of on-going and overall burden of the infection among this cohort of HIV infected patients in Offa Kwara state. This is in consonance with earlier studies by Fowotade et al. ${ }^{21}$ and Deborah et al. ${ }^{22}$ which reported IgM levels of $11.1 \%$ among HIV patients in a tertiary health facility in Ilorin, Kwara state and 10.5\% among pregnant women in a secondary health facility in Kafanchan, Kaduna states respectively. This indicates significant level of acute/ongoing CMV infection among both cohorts of HIV infected and non-infected individuals in our society. Lower CMV IgM levels have earlier been reported among HIV patients in Benin $(7.0 \%)^{23}$, pregnant women in Benue $(3.5 \%)^{24}$ and outside the country among pregnant women in Kenya $(8.1 \%)^{25}$. On the other hand, higher levels of $13.0 \%$ and $28.0 \%$ of CMV IgM antibodies have equally been reported by Musa et al. ${ }^{26}$ and Oladipo et al. ${ }^{27}$ among HIV patients in Kano and among blood donors in Ogbomoso, Oyo state respectively. Compared to significantly lower rates reported from more developed countries $^{28,29,30}$, the observation of high active CMV infection in our study and indeed other parts of Nigeria could signify high level of re-activation or continued ongoing new infections. This is particularly worrisome and reinforces the need to address the serious problem which high endemicity brings in the study population.

In the event of re-activation, the fact that majority of these patients are already on HAART and none was reported as having any clinical manifestation of AIDS (data not shown) suggests other factors rather than immunosuppression as the cause of the re-activation.

The high prevalence of $73.6 \%$ of CMV IgG antibodies recorded in this study is comparable to the $77 \%$ IgG antibody level reported by Pennap and Ahmed ${ }^{31}$ among HIV patients in Nasarawa state. However, this rate is slightly lower compared to prevalence rates reported by other researchers from different parts of Nigeria. Seroprevalence of CMV IgG of $93.3 \%$ was reported by Umeh 
et al. ${ }^{24}$ among pregnant women in Benue state. Similarly, 93.9\% seroprevalence was reported by Fowotade et al. ${ }^{21}$ among HIV patients in Ilorin. Yet higher prevalence rates for CMV IgG antibodies have been reported among HIV patients by Ojide et al. ${ }^{23}$ and Kida et al. ${ }^{32}$ in Benin, Edo state and Maiduguri, Borno state respectively. Elsewhere outside the country, prevalence of $77.3 \%{ }^{25}$ and $90.0 \%$ $100.0 \% \%^{33,34}$ were reported from Kenya and India respectively. The high prevalence recorded in Nigeria and other developing countries like Kenya and India contrasts with lower prevalence rates recorded in more developed countries in which prevalence ranges from $38.0 \%-75.0 \%$. Its seroprevalence among adult populations in the USA, Australia and Europe has been estimated at between 36.0\%$77.0 \%{ }^{35}$. Cultural and economic as well as racial differences between the developed and developing countries might partly explain this observed difference in prevalence rates. This view is strongly supported by studies which associated poor nutrition and low weight ${ }^{36}$ and crowded living conditions ${ }^{37}$ with increased CMV seroprevalence in African studies. Poor nutrition and crowded living conditions which are associated with poor economic conditions are more likely in developing than developed countries.

This study also showed significantly higher rate of acute/ active CMV infection among the male patients than their female counterparts as demonstrated by significantly higher IgM in males than females. Previous infection (shown by $\operatorname{IgG}$ ) was also higher in males than females although the difference is not statistically significant $(p$ $>0.05$ ). Similar studies by Ojide et al. ${ }^{23}$ and Fowotade et $\mathrm{al}^{21}$ on HIV-infected individuals failed to record any significant association between both CMV-specific IgM and $\mathrm{IgG}$ antibodies and gender of the patients. The significantly higher rate of acute/active infection among males than females in this study suggests more exposure of males to factors that lead to re-activation or re-infection of CMV in the study locality and needs to be investigated. Furthermore, age dependence in the distribution of both anti-CMV IgM and IgG antibodies was demonstrated in this study. The higher prevalence of acute infection recorded among patients $\leq 20$ years can be attributed to low level of education among this group compared to their older counterparts. Furthermore, these patients are teenagers and more likely to engage in risky behaviours that aids transmission. Similarly, somewhat high prevalence of
IgM antibody recorded among older patients (51-60 years and $>60$ years) could be as a result of re-activation as the virus is known to re-activate in old age due to weakened immunity. On the other hand, higher prevalence of previous infection (IgG antibodies) among older patients (51-60 years and $>60$ years) demonstrates the cumulative nature of the infection since the virus maintains latency in the body and an infected individual remains infected for life. Higher prevalence of previous/latent infection is therefore expected among older population. Similar trend was also reported by Fowotade et al. ${ }^{21}$

Our analysis also showed no association between anti-CMV IgM antibody level and occupation of the patients $(p>0.05)$ while anti-CMV IgG antibody level is significantly associated $(\mathrm{p}<0.05)$ with patients' occupation. Highest prevalence of both $\operatorname{IgM}$ and $\operatorname{IgG}$ antibodies among this cohort is reported among the students population. While higher IgM antibody among the students can be explained by the earlier view that risky behaviours among the students may be higher due to teenage tendencies and low level of education (majority are in primary and secondary schools), no reason for high IgG antibody among this group could be advanced at this point since higher $\operatorname{IgG}$ antibody is expected among other occupational groups with older patients. Similar studies by Umeh et al. ${ }^{24}$ and Fowotade et al. ${ }^{21}$ among pregnant women and HIV-patients respectively did not find any significant association between the distribution of both anti-CMV IgM and IgG antibodies and occupation of their subjects. Although not statistically significant $(X 2=2.55, \mathrm{p}=0.4663)$, the prevalence of anti-CMV IgM antibody is slightly higher among single than married patients. The antibody was not detected among the widows and divorced patients. On the other hand, there was statistical association $(\mathrm{X} 2=9.12, \mathrm{p}=0.0277)$ in the distribution of anti-CMV IgG antibody among the different marital groups. There was an IgG prevalence of $90.9 \%$ among the divorced patients. This is followed by singles $(75.3 \%)$ and married patients $(73.6 \%)$ respectively while the least prevalence $(28.6 \%)$ was recorded among the widows. Similar study by Fowotade et al. ${ }^{21}$ reported significant association in the distribution of both IgM and IgG antibodies among different marital groups.

Majority, $98.6 \%$ (355/360) of the participants in this study were on HAART while the remaining, 1.4\% (5/360) were 
antiretroviral treatment (ART) naïve at the time of study. Among those on HAART, 11.8\% (42/355) tested positive to anti-CMV IgM antibody while $74.1 \%$ (263/355) also tested positive to anti-CMV IgG antibody. Forty percent $(40.0 \%)$ prevalence of anti-CMV IgG antibody was recorded among the ART naive patients while IgM antibody was not detected among them (Figure 1). Furthermore, none of the patients was reported of having any clinical manifestation of AIDS and none was receiving any anti-herpes drugs (AHDs) (data not shown) at the time of the study. Although the sample size is skewed in favour of HAART experienced compared to naïve patients, detection of anti-CMV IgM antibody among the former group and not among the latter indicates that re-activation/or new infection of CMV occurs independent of HAART-mediated HIV suppression. Similar result was also recorded for $\mathrm{IgG}$ antibody level. Higher prevalence $(74.1 \%)$ of $\mathrm{IgG}$ antibody was recorded among HAART experienced than naïve patients with prevalence of $40.0 \%$. This therefore underscores the need to incorporate AHDs in the treatment regimen for HIV-infected patients in this locality considering the reported high prevalence. This is in consonance with previous report by Pennap and $A_{h m e d}{ }^{31}$ in which higher prevalence of anti-CMV IgG antibody was reported among drug experienced than naïve patients. It is however a clear departure from a trend reported by Fowotade et al. ${ }^{21}$ in which higher prevalence of both IgM and IgG antibodies were reported among drug naïve than experienced patients.

Since $\mathrm{CD}^{+}$cell count is an acceptable measure of immune status among HIV-infected individuals, we also analysed the result based on the $\mathrm{CD}^{+}$cell count of the patients. Presently in Nigeria, antiretroviral therapy for HIV-infected individuals commences when the $\mathrm{CD}^{+}$ cell count declines to below $350 / \mu \mathrm{L}$. Hence, we grouped the patients into two based on their $\mathrm{CD}^{+}$cell count; those with $\mathrm{CD}^{+}$cell count of $\leq 350 / \mu \mathrm{L}$ and those with $\mathrm{CD}^{+}$cell count of $>350 / \mu \mathrm{L}$. Our analysis surprisingly showed higher prevalence of both anti-CMV IgM and IgG antibodies among patients with higher $\mathrm{CD}^{+}$cell counts $(\leq 350 / \mu \mathrm{L})$ compared to their counterparts with lower $\mathrm{CD}^{+}$cell counts $(\leq 350 / \mu \mathrm{L})$ although the difference is not statistically significant $(p>0.05)$ (Figure 2$)$. Similar studies in Benin, Nigeria ${ }^{23}$ and $\operatorname{Iran}^{38}$ also found no significant association between the $\mathrm{CD}^{+}$cell level and seroprevalence of CMV. The reason for this observation is not immediately known to this study. However, since majority of the study participants are on HAART which affects $\mathrm{CD}^{+}$cell counts, type of therapy and duration may be likely factors.

\section{Conclusion}

The prevalence of both latent and active CMV infection is high among HIV-1 infected individuals in Offa, Kwara state Nigeria and occurs irrespective of HAART status. This suggests that the patients still engage in risky behaviours that aids transmission of the virus. In addition to mass education aimed at sensitizing the general public, there is also the need to incorporate anti-herpes medications in the treatment regimen of the HIV-1 patients to reduce $\mathrm{CMV}$ associated morbidity and mortality.

\section{Acknowledgments}

The authors wish to acknowledge Kwara state Ministry of Health for giving the approval to conduct the research. We also thank the management of General hospital Offa for their support and facilitating access to the participants in this study.

\section{Competing interests}

Authors have declared that no competing interests exist.

\section{References}

1. Brooks JT, Kaplan JE, Holmes KK, Benson C, Pau A, Masur H. HIV Associated Opportunistic Infections-Going, Going,But Not Gone: The Continued Need for Prevention and Treatment Guidelines. Clin Infect Dis. 2009; 48 (5): 609-611

2. Fowler KB, Stagno S, Pass RF. Maternal immunity and prevention of congenital cytomegalovirus infection. JAMA 2003; 289: 1008-1011. PubMed.

3. Hecker M, Qiu D, Marquardt K, Bein G, Hackstein $\mathrm{H}$. Continuous cytomegalovirus seroconversion in a large group of healthy blood donors. Vox Sang. 2004; 86: 4144. PubMed.

4. Robain M, Carre N, Dussaix E, Salmon-Ceron D, Meyer L. Incidence and sexual risk factors of cytomegalovirus seroconversion in HIV infected subjects. Sex Transm Dis. 1998; 25: 476-480. PubMed.

5. Britt W. Manifestations of human cytomegalovirus infection: proposed mechanisms of acute and chronic disease. Curr Top Microbiol Immunol. 2008; 325: 417-470.

6. Greenberg MS, Glick M, Nghiem L, Stewart JC, Hodinka R, Dubin G. Relationship of cytomegalovirus to sali- 
vary gland dysfunction in HIV-infected patients. Oral Surg Oral Med Oral Pathol Oral Radiol Endod. 1997; 83: 334-339 7. Casiglia JW, Woo SB. Oral manifestations of HIV infection. Clin Dermatol. 2000; 18: 541-551. PubMed.

8. Basawaraju A, Pratibha MM, Vijayadurga S. The Reactivation of Cytomegalovirus (CMV) Infection in HIV Infected Patients. J Clin Diag Res. 2011; 5: 749 - 751.

9. Frenkel LD, Gaur S, Tsolla M, Scudder R, Howell R, Kesarwala H. Cytomegalovirus infection in children with AIDS. Rev Infect Dis. 1990; 12: 5820- 826. PubMed.

10. Chandwani S, Kaul A, Bebenroth D, et al. Cytomegalovirus infection in human immunodeficiency virus type 1-infected children. PediatrInfect Dis J. 1996; 15: 310-314

11. Kitchen BJ, Engler HD, Gill VJ, et al. Cytomegalovirus infection in children with human immunodeficiency virus infection. Pediatr Infect Dis J. 1997; 16: 358-363

12. Griffiths PD. Herpesviruses and AIDS. J Antimicrob Chemother. 1996; 37: 87-95

13. Domachowske JB. Pediatric human immunodeficiency virus infection. Clin Microbiol Rev. 1996; 9: 448-468. PubMed.

14. Carney WP, Iacoviello V, Hirsch MS. Functional properties of T lymphocytes and their subsets in cytomegalovirus mononucleosis. J Immunol. 1983; 130: 390-393

15. Gerard L, Leport C, Flandre P, et al. Cytomegalovirus (CMV) viremia and the $\mathrm{CD}^{+}$lymphocyte count as predictors of CMV disease in patients infected with human immunodeficiency virus. Clin Infect Dis. 1997; 24: 836-840 16. Rabkin CS, Hatzakis A, Griffiths PD, et al. Cytomegalovirus infection and risk of AIDS in human immunodeficiency virus-infected hemophilia patients: National Cancer Institute Multicenter Hemophilia Cohort Study Group. J Infect Dis. 1993; 168: 1260-1263

17. Shepp DH, Moses JE, Kaplan MH. Seroepidemiology of cytomegalovirus in patients with advanced HIV disease: influence on disease expression and survival. $J$ Acquir Immune Defic Syndr Hum Retrovirol. 1996; 11: 460468

18. Webster A. Cytomegalovirus as a possible cofactor in HIV disease progression. I Acquir Immune Defic Syndr. 1991; 4(Suppl 1):S47-S52

19. Gallant JE, Moore RD, Richman DD, Keruly J, Chaisson RE. Incidence and natural history of cytomegalovirus disease in patients with advanced human immunodeficiency virus disease treated with zidovudine. J Infect Dis. 1992;166: 1223-1227

20. Drew WL. Diagnosis of cytomegalovirus infection. Rev Infect Dis. 1988; 10 Suppl 3:S468-476
21. Fowotade A, Okonko IO, Agbede OO, Suleiman ST. High seropositivity of $\operatorname{IgG}$ and $\operatorname{IgM}$ antibodies against cytomegalovirus (CMV) among HIV-1 seropositive patients in Ilorin, Nigeria. Afr Health Sci. 2015; 15(1): 1-9. PubMed

22. Deborah SE, Isaac UE, Nwankiti O, Ishaku BS, Musa MA. Sero-Prevalence of Cytomegalovirus (IgM) Antibodies among Pregnant Women Attending Ante-natal Clinic at the General Hospital Kafanchan, Kaduna State Nigeria. Br Microb Res J. 2015; 9(5): 1-6

23. Ojide CK, Kalu EI, Nwadike VU, Ogbaini-Emovon $\mathrm{E}$ and Omoti C. Seroprevalence of Cytomegalovirus among HIV-Infected Adult Patients on HAART. Int J Trop Dis Health. 2013; 3(3): 233-241

24. Umeh EU, Onoja TO, Aguoru CU and Umeh JC. Seroprevalence of Cytomegalovirus Antibodies in Pregnant Women, Benue State, Nigeria. Infect Dis Ther. 2015; 3: 242. 25. Maingi $Z$ and Nyamache AK. Seroprevalence of Cytomegalo Virus (CMV) among pregnant women in Thika, Kenya. BMC Research Notes. 2014, 7:794

26. Musa AM, Taura DW, Mukhtar MD, Koki YA, Adamu S. Studies on Cytomegalovirus Infection among HIV Positive Patients Attending Infectious Diseases Hospital, Kano State, Nigeria. Greener Journal of Epidemiology and Public Health. 2014; 2 (1): 032-036

27. Oladipo EK, Akinpelu OO, Oladipo AA, Edowhorhu G. Seroprevalence of Cytomegalovirus (CMV) among Blood Donors at Bowen University Teaching Hospital Ogbomoso. Am J Med Biol Res. 2014; 2(3): 72-75

28. Souza MA. Passos AM, Treitinger A, Spada C. Seroprevalence of Cytomegalovirus antibodies in blood donors in Southern, Brazil. Rev Soc Bras Med Trop. 2010; 43:359-361.

29. Dollard SC, Staras SAS, Amin MM, Schmid DS and Cannon MJ. National Prevalence Estimates for Cytomegalovirus IgM and IgG Avidity and Association between High IgM Antibody Titre and Low IgG Avidity. Clin Vaccine Immunol. 2011; 18: 1895-1899.

30. Uysal A, Taner CE, Cuce M, et al. Cytomegalovirus and Rubella seroprevalence in pregnant women in Izmir/ Turkey: follow-up and result of pregnancy outcome. Arch Gynecol Obstet. 2012; 286: 605-608.

31. Pennap GR and Ahmed HO. Seroprevalence of Cytomegalo Virus Infection among HIV Patients Accessing Healthcare in Federal Medical Centre Keffi, Nigeria. Int J Trop Dis Health. 2016; 17(3): 1-6

32. Kida IM, Denue BA, Bakki B, et al. Seroprevalence of and Risk Factors for Cytomegalovirus among HIV-In- 
fected Patients at University of Maiduguri Teaching Hospital, Nigeria. Open J Immunol. 2014; 4:54-59

33. Madhavan HN, Prakash K, Agarwal SC. Cytomegalovirus infections in Pondicherry: a serological survey. Indian J Med Res. 1974; 62: 297-300. PubMed.

34. Kothari A, Ramachandrum VG, Gupta P, Singh B, Talwar V. Seroprevalence of Cytomegalovirus among voluntary blood donors in Dehli, India. $J$ Health Popul Nutr. 2002; 20(4): 348-351.

35. Adland E, Klenerman P, Goulder P, Matthews PC. Ongoing burden of disease and mortality from HIV/ CMV coinfection in Africa in the antiretroviral therapy era. Front Microbiol. 2015; 6: 1016
36. Tembo J, Kabwe M, Chilukutu L, et al. Prevalence and risk factors for Betaherpesvirus DNAemia in Children $>3$ Weeks and $<2$ Years of age admitted to a large Referral Hospital in Sub-Saharan Africa. Clin. Infect. Dis. 2015; 60:423-431

37. Alao OO, Mamman A, Araoye MO, Joseph E. Effect of demographic variables on cytomegalovirusantibody seropositivity among prospective blood donors in Jos, Nigeria. Niger. Postgrad. Med. J. 2009; 16: 139-142

38. Mehrkhani F, Jam S, Sabzvari D, Fattahi F, Kourorian $\mathrm{Z}$, SeyedAlinaghi S. Cytomegalovirus Co-Infection in Patients with Human Immunodeficiency Virus in Iran. Acta Medica Iranica. 2011; 49(8): 551-555. PubMed. 